\title{
Wykorzystanie danych biometrycznych w szkole
}

\author{
Wyrok Wojewódzkiego Sądu Administracyjnego w Warszawie \\ z dnia 7 sierpnia 2020 r., II SA/Wa 809/20
}

1. Wystarczy, aby możliwa była choćby pośrednia identyfikacja osoby, by dane jej dotyczące stanowiły jej dane osobowe, co jednoznacznie wynika $z$ definicji zawartej w art. 4 pkt 1 RODO. Ponadto, $z$ uwagi na charakter przetwarzania (specjalne przetwarzanie techniczne), a także charakter samych danych, które dotyczą cech fizjologicznych i fizycznych, stwierdzić należy, że przetwarzane do postaci cyfrowej informacje o charakterystycznych punktach linii papilarnych palców dzieci stanowią dane biometryczne, służą bowiem do zautomatyzowanej weryfikacji uprawnienia konkretnej osoby fizycznej.

2. Starając się literalnie odczytać wymogi adekwatności i minimalizacji, można dojść do wniosku, że w praktyce nie jest łatwo ich ze sobą pogodzić, albowiem adekwatność zakłada dokonanie oceny przydatności określonego rodzaju danych do realizacji celu, natomiast minimalizacja prowadzi do uznania, że jeśli cel można osiągnąć bez przetwarzania określonego rodzaju danych, to nie należy takich danych przetwarzać. (...) Można pogodzić ze sobą te dwa nie do końca spójne wymogi, uznając, że ich spełnienie należy oceniać łącznie, co w konsekwencji oznacza, że nie powinno się przyznawać prymatu minimalizacji kosztem adekwatności. W tej sytuacji, (...) za dopuszczalne uznać należy przetwarzanie danych w nieco szerszym zakresie niż tylko (...) konieczne minimum, pod warunkiem że przetwarzane dane mają ścisły związek z realizacją celu (np. ułatwiają jego osiągnięcie).

\section{Arwid Mednis}

Uniwersytet Warszawski

arwid.mednis@uw.edu.pl

ORCID: 0000-0001-8130-7108

https://doi.org/10.26881/gsp.2021.4.08

Glosowany wyrok zasługuje na uwagę z kilku powodów. Po pierwsze, jest to jedno z nielicznych orzeczeń wydanych dotychczas pod rządami rozporządzenia Parlamentu Europejskiego i Rady UE 2016/679 z dnia 27 kwietnia 2016 r. w sprawie ochrony osób fizycznych w związku z przetwarzaniem danych osobowych i w sprawie swobodnego przepływu takich danych oraz uchylenia dyrektywy 95/46/WE (ogólne rozporządzenie 
o ochronie danych) ', w których Wojewódzki Sąd Administracyjny w Warszawie nie podzielił stanowiska organu ochrony danych ${ }^{2}$. Po drugie, wyrokowi nie można odmówić wyjątkowej wnikliwości uzasadnienia. Po trzecie wreszcie, komentowany wyrok jest pierwszym orzeczeniem sądowym w Polsce zapadłym pod rządami RODO, które dotyczyło wykorzystania danych biometrycznych ${ }^{3}$.

Jednak głównym powodem, dla którego warto bliżej omówić ów wyrok, jest kwestia rozumienia jednej z kluczowych zasad RODO, jaką jest zasada minimalizacji, przede wszystkim w kontekście wykorzystywania danych szczególnej kategorii za zgodą osób, których dane te dotyczą.

Należałoby zatem przypomnieć krótko stan faktyczny sprawy. Szkoła podstawowa w Gdańsku od września 2015 r. wykorzystywała czytnik biometryczny w celu weryfikacji uiszczenia opłaty za posiłki uczniów. Czytnik umieszczono przy wejściu do stołówki szkolnej, tak aby na bieżąco identyfikować dzieci pobierające posiłki w stołówce oraz weryfikować uiszczenie opłaty za posiłek $w$ danym dniu. Identyfikacja i weryfikacja odbywały się na podstawie odcisku palca ucznia. Szkoła nie posiadała żadnego zbioru, który zawierałby obrazy linii papilarnych dzieci. Dane były gromadzone tylko w czytniku w postaci zapisu ciągu bajtów. W trakcie odczytu czytnik porównywał, czy istnieje odpowiedni zapis cyfrowy, a w przypadku, gdy porównanie wypadło pomyślnie, wysyłał do programu tylko numer pozycji przypisany do konkretnego dziecka, kończąc w ten sposób weryfikację dokonanej uprzednio płatności.

Szkoła pozyskiwała dane uczniów na podstawie pisemnej zgody rodzica (opiekuna prawnego). Rodzic w umowie o korzystanie z posiłków w stołówce szkolnej miał możliwość wyboru: wyrażenia lub niewyrażenia zgody na korzystanie z czytnika na odcisk palca. Rodzice byli informowani o takiej możliwości na stronie internetowej stołówki szkolnej. Na stronie umieszczono również zasady wydawania obiadów, zgodnie z którymi uczniowie, którzy nie posiadają identyfikacji biometrycznej, przepuszczają wszystkich i oczekują na końcu kolejki, aż wszyscy uczniowie z identyfikacją biometryczną wejdą do stołówki. Po ich wejściu rozpoczyna się wpuszczanie pojedynczo uczniów bez identyfikacji biometrycznej.

Po podpisaniu umowy i wyrażeniu zgody przez rodzica na korzystanie z czytnika biometrycznego uczeń był rejestrowany w systemie ewidencji wpłat i posiłków (SEWiP) poprzez wprowadzenie jego imienia, nazwiska, klasy oraz imienia, nazwiska, adresu e-mail, numeru telefonu kontaktowego rodzica. Następnie (jeśli rodzic wyraził zgodę) dochodziło do rejestracji wzorca odcisku palca dziecka w czytniku.

Po rozwiązaniu umowy o korzystanie z obiadów w stołówce szkolnej, dane potrzebne do identyfikacji (tj. ciąg bajtów zapisany w czytniku) były usuwane, z zastrzeżeniem

1 Dz. Urz. UE L 119, s. 1 ze zm.; dalej: RODO.

2 Należy podkreślić, że glosowany wyrok jest przedmiotem skargi kasacyjnej Prezesa Urzędu Ochrony Danych Osobowych. Jednak do chwili złożenia niniejszej glosy do publikacji, rozstrzygnięcie Naczelnego Sądu Administracyjnego nie było znane.

3 Nie jest to jednak pierwszy w Polsce wyrok dotyczący przetwarzania danych biometrycznych. Warto wspomnieć choćby wyrok Naczelnego Sądu Administracyjnego z dnia 1 grudnia 2009 r., I OSK 249/09, wydany pod rządami ustawy o ochronie danych osobowych z 1997 r. 
że pozostawiano kopię archiwizacyjną na karcie micro SD, która przechowywana była w zabezpieczonym pomieszczeniu. W sytuacji gdy uczeń przestawał korzystać ze stołówki, a umowa nie została rozwiązana i rodzic nie wycofał zgody, wzorzec biometryczny zapisany w czytniku przechowywany był do czasu rozwiązania umowy lub do zakończenia roku szkolnego. Na czas wakacji wzorzec biometryczny pozostawał zapisany w czytniku i na karcie SD. W przypadku nieprzedłużenia umowy o korzystanie z obiadów w stołówce szkolnej na nowy rok szkolny dane były usuwane najpóźniej do września każdego roku.

Istotnym elementem stanu faktycznego była liczba uczniów. W roku szkolnym 2018/2019 do Szkoły uczęszczało 1247 uczniów, z czego 603 korzystało z czytnika biometrycznego, a 2 uczniów z alternatywnego systemu identyfikacji. W roku szkolnym 2019/2020 do szkoły uczęszczało 1121 uczniów, z czego 680 uczniów korzystało z czytnika biometrycznego, a 4 uczniów z alternatywnego systemu identyfikacji.

Warto odnotować, że władze szkoły stały na stanowisku, że dane przetwarzane w systemie nie są danymi biometrycznymi.

Decyzją z dnia 18 lutego 2020 r. Prezes Urzędu Ochrony Danych Osobowych (PUODO) stwierdził naruszenie przez szkołę art. 5 ust. 1 lit. c RODO (zasada minimalizacji danych) oraz art. 9 ust. 1 RODO (zakaz przetwarzania szczególnych kategorii danych). Jednocześnie PUODO nakazał szkole usunięcie danych osobowych w zakresie przetworzonych do postaci cyfrowej informacji o charakterystycznych punktach linii papilarnych palców dzieci korzystających z usług stołówki szkolnej, zaprzestanie zbierania powyższych danych osobowych oraz nałożył na szkołę karę pieniężną w wysokości 20.000 zł. Szkoła wniosła skargę na powyższą decyzję organu. Omawianym w niniejszej glosie wyrokiem z dnia 7 sierpnia 2020 r. Wojewódzki Sąd Administracyjny w Warszawie uchylił decyzję PUODO.

W dalszej części tekstu skupię się tylko na najważniejszych, moim zdaniem, elementach sprawy. Po pierwsze - na kwestii przesłanek legalności przetwarzania danych biometrycznych, a po drugie - na zasadzie minimalizacji danych i jej relacji do przesłanki zgody. Pominę natomiast inne kwestie, m.in. te związane z wysokością kary pieniężnej i przesłankami jej szacowania.

W pierwszej kolejności należy stwierdzić, że wbrew twierdzeniom szkoły, dane służące do identyfikacji i weryfikacji uprawnień do posiłków przetwarzane w czytniku i na innych nośnikach archiwizacyjnych to bez wątpienia dane biometryczne. Artykuł 4 pkt 14 RODO określa dane biometryczne jako dane osobowe, które wynikają ze specjalnego przetwarzania technicznego, dotyczą cech fizycznych, fizjologicznych lub behawioralnych osoby fizycznej oraz umożliwiają lub potwierdzają jednoznaczną identyfikację tej osoby, takie jak wizerunek twarzy lub dane daktyloskopijne. Istotą definicji są zatem trzy następujące elementy:

- specjalne przetwarzanie techniczne;

- odniesienie do cech fizycznych, fizjologicznych lub behawioralnych, które są w zasadzie niezmienne i niepowtarzalne oraz

- możliwość jednoznacznej identyfikacji osoby. 
Pomimo tego, że szkoła nie przechowywała obrazów odcisków palców, to jednak przedstawienie ich w czytniku w formie zapisu cyfrowego, który pozwalał na jednoznaczną identyfikację, oznacza, że były one danymi biometrycznymi. Słusznie zatem zarówno organ, jak i sąd w tym zakresie odmówiły uznania argumentacji skarżącej szkoły.

W art. 9 ust. 1 RODO zabrania się przetwarzania określonych (szczególnych) kategorii danych osobowych, wśród których są m.in. dane biometryczne, przetwarzane w celu jednoznacznego zidentyfikowania osoby fizycznej. Prezes Urzędu Ochrony Danych Osobowych, powołując się na motyw 38 RODO, podkreśla w decyzji, że niezależnie od tego, czy mamy do czynienia z danymi zwykłymi czy szczególnymi, dane osobowe dzieci wymagają specjalnej ochrony, ponieważ dzieci mogą być mniej świadome ryzyka, konsekwencji, zabezpieczeń i praw przysługujących im w związku z przetwarzaniem danych osobowych. Wydaje się jednak, że uwaga ta jest nietrafna w kontekście omawianej sprawy, ponieważ motyw 38, w mojej ocenie, dotyczy przede wszystkim sytuacji, gdy dzieci, korzystając z usług w internecie, udostępniają swoje dane $w$ rozmaitych serwisach.

Wyjątki od zakazu przetwarzania szczególnych kategorii danych zostały określone $w$ art. 9 ust. 2 RODO. Jak słusznie wskazuje organ, katalog wymieniony w tym przepisie jest zamknięty. „Każda z przesłanek legalizujących proces przetwarzania danych osobowych ma charakter autonomiczny i niezależny. Oznacza to, że przesłanki te co do zasady są równoprawne, a wobec tego spełnienie co najmniej jednej z nich stanowi o zgodnym z prawem przetwarzaniu danych osobowych" - podkreśla PUODO w dalszej części uzasadnienia. Jednym z wyjątków jest wyraźna zgoda podmiotu danych. W omawianej sprawie szkoła powoływała się na zgody wyrażone przez rodziców (opiekunów prawnych) uczniów. Organ zwraca jednak uwagę, że zgoda powinna być m.in. dobrowolna, a o dobrowolności zgody nie można mówić w przypadku wyraźnego braku równowagi w relacji pomiędzy administratorem a podmiotem danych. Jednakże dalsza część uzasadnienia decyzji odnosząca się do zgody i innych przesłanek jest co najmniej niespójna. Wbrew wcześniejszemu stwierdzeniu o równoważnym charakterze wszystkich przesłanek z art. 9 ust. 2 RODO, organ stwierdza dalej, że „zgoda stanowi podstawę legalizującą przetwarzanie danych osobowych jedynie wtedy, gdy nie istnieją inne przesłanki na to przetwarzanie". Jednocześnie PUODO przeprowadza analizę przepisów ustawy z dnia 14 grudnia 2016 r. - Prawo oświatowe (Dz. U. z 2019 r., poz. 1148; dalej: u.p.o.).

Organ zauważa, że zgodnie $z$ art. 106 tej ustawy w celu zapewnienia prawidłowej realizacji zadań opiekuńczych, w szczególności wspierania prawidłowego rozwoju uczniów, szkoła może zorganizować stołówkę. W związku z tym stwierdza, że „podstawą przetwarzania jakichkolwiek danych osobowych dzieci w związku z realizacją tego zadania szkoły nie mogła być zgoda, ponieważ podstawą do przetwarzania danych osobowych dzieci w tym celu przez Szkołę jest art. 6 ust. 1 lit. e RODO, zgodnie z którym przetwarzanie jest zgodne z prawem między innymi gdy przetwarzanie jest niezbędne do wykonania zadania realizowanego $\mathrm{w}$ interesie publicznym lub $\mathrm{w}$ ramach sprawowania władzy publicznej powierzonej administratorowi". Prezes Urzędu 
Ochrony Danych Osobowych wywodzi z tego, że szkoła przetwarza dane osobowe ucznia na podstawie przepisów prawa, wykonując swoje ustawowe zadania. Nie potrzebuje zatem odrębnej zgody rodziców bądź pełnoletniego ucznia na przetwarzanie danych osobowych w związku z realizacją tych zadań, tj. świadczeniem usług przez stołówkę szkolną. Jednocześnie organ stwierdza, że przepisy prawa określające, jakie dane o uczniach może gromadzić szkoła, nie przewidują możliwości zbierania danych biometrycznych.

W mojej ocenie, pogląd, że zgoda jest przesłanką legalizującą przetwarzanie danych osobowych tylko wtedy, gdy nie można zastosować innych przesłanek, jest niczym nieuzasadniony. Ponadto, jest sprzeczny z wyrażonym przez organ w innym miejscu uzasadnienia poglądem, zgodnie z którym wszystkie przesłanki są równoważne i autonomiczne. Dotyczy to również przesłanek zawartych w art. 9 ust. 2 RODO ${ }^{4}$. Nie jest również zrozumiałe, dlaczego organ, stwierdziwszy że ma do czynienia z danymi szczególnej kategorii, analizuje podstawy opisane w art. 6 ust. 1 RODO zamiast tych zawartych w art. 9 ust. 2 RODO. Ponadto, jeśli organ uznał, że nie można zastosować przesłanki, o której mowa w art. 6 ust. 1 lit. e RODO i nie widzi innych podstaw prawnych przetwarzania, powinien był, zgodnie z powyższym poglądem, rozważyć przesłankę zgody. Niezależnie od powyższego, dokonana przez organ wykładnia ustawowych uprawnień szkoły budzi co najmniej poważne wątpliwości. Przepisy prawa oświatowego nie zawierają listy danych osobowych uczniów, które mogą być przetwarzane przez szkołę; jedynie art. 30a u.p.o. zobowiązuje jednostki oświatowe, w tym szkoły, do przetwarzania danych w zakresie niezbędnym do realizacji zadań ustawowych. W mojej ocenie, nie można na tej podstawie wykluczyć zastosowania przez szkołę przesłanki zgody. Restrykcyjne podejście eliminujące taką możliwość, wyłączyłoby bowiem całą sferę działań organizatorskich jednostek oświatowych, a więc sferę, która jest związana z zadaniami oświatowymi, ale nie jest szczegółowo uregulowana przepisami prawa.

Wojewódzki Sąd Administracyjny (WSA) w Warszawie zasadnie zatem pominął powyższy wywód PUODO i dopuścił zgodę jako podstawę przetwarzania danych uczniów korzystających ze stołówki. Uznał, że pisemne oświadczenia rodziców, w których wyraźnie wskazano cel przetwarzania danych biometrycznych, stanowią jednoznaczną i niebudzącą wątpliwości zgodę na ich przetwarzanie w określonym celu, i tym samym świadczą o spełnieniu przesłanki, o której mowa w art. 9 ust. 2 lit. a RODO. W tym miejscu pozostaje jedynie wyrazić wątpliwość co do dobrowolności zgody wyrażanej przez rodziców. Cecha ta wyraża się bowiem m.in. w braku negatywnych konsekwencji odmowy udzielenia zgody ${ }^{5}$. Skutkiem odmowy udzielenia zgody w omawianym przypadku jest, na co zwrócił uwagę organ, dłuższe oczekiwanie na posiłek przez uczniów, których rodzice nie wyrazili zgody na biometryczną weryfikację faktu opłacenia posiłku. Kwestia ta wymaga jednak szerszej analizy, która wykracza poza ramy niniejszej

\footnotetext{
4 Tak m.in. P. Litwiński [w:] Ogólne rozporzq̨dzenie o ochronie danych osobowych. Ustawa o ochronie danych osobowych. Wybrane przepisy sektorowe. Komentarz, red. idem, Warszawa 2021, s. 205.

5 Wytyczne 5/2020 dotyczące zgody na mocy rozporządzenia 2016/679, wersja 1.1 przyjęta dnia 4 maja 2020 r., s. 7, https://edpb.europa.eu/sites/default/files/files/file1/edpb_guidelines_202005_ consent_pl.pdf [dostęp: 25.11.2021].
} 
glosy. Warto jedynie wskazać, że odmowa udzielenia zgody praktycznie zawsze wiąże się z jakimś negatywnym skutkiem, pozostaje jedynie pytanie o to, czy skutek w postaci opóźnienia w świadczeniu usługi pozwalałby na zakwestionowanie dobrowolności zgody rodziców.

Szerzej natomiast chciałbym skupić się na zasadzie minimalizacji danych. Zarówno organ, jak i sąd słusznie wskazują, że obowiązek przestrzegania tej zasady jest niezależny od legitymowania się przesłanką legalności przetwarzania danych. Dotyczy to również przetwarzania danych osobowych na podstawie zgody. Innymi słowy, administrator przetwarzający dane na podstawie pozyskanej zgody jest nadal zobowiązany do przestrzegania zasady minimalizacji danych. Nie ulega również wątpliwości, że zasada ta, podobnie jak pozostałe wymienione $w$ art. 5 RODO, ma charakter normatywny i jest samoistnym obowiązkiem nałożonym na administratora.

Zasada minimalizacji wyrażona $w$ art. 5 ust. 1 lit. c RODO stanowi, że dane osobowe muszą być adekwatne, stosowne oraz ograniczone do tego, co niezbędne do celów, w których są przetwarzane. $Z$ językowego punktu widzenia istnieją na tym tle różne możliwości interpretacyjne. Wydaje się bowiem, że „minimalizacja” $i$ „niezbęd-

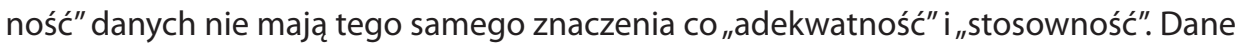
adekwatne do celu to dane "odpowiednie", a nie tylko "niezbędne". W praktyce ma to ogromne znaczenie, ponieważ zakres danych odpowiednich do danego celu może być znacznie szerszy od danych minimalnych, niezbędnych do realizacji tego celu.

W obowiązującym przed datą zastosowania RODO (tj. 25 maja 2018 r.) stanie prawnym, przepisy stawiały wymóg, aby dane były „prawidłowe, stosowne oraz nienadmierne ilościowo w stosunku do celów, dla których zostały zgromadzone i/lub dalej przetworzone" (art. 6 ust. 1 lit. c dyrektywy 95/46 ${ }^{6}$ ). W wersji angielskiej tej dyrektywy użyto sformułowania o identycznym znaczeniu (adequate, relevant and not excessive in relation to the purposes for which they are collected and/or further processed).

Zgodnie z motywem 28 powyżzzej dyrektywy, "dane muszą być adekwatne, właściwe i nie wykraczać poza cele, dla których są przetwarzane" (the data must be adequate, relevant and not excessive in relation to the purposes for which they are processed). W polskiej ustawie implementującej dyrektywę $95 / 46^{7}$ w art. 26 ust. 1 pkt 3 znalazł się wymóg, aby dane były merytorycznie poprawne i adekwatne w stosunku do celów, $w$ jakich są przetwarzane. Tak więc $w$ poprzednim stanie prawnym w przepisach nie wymagano, aby przetwarzanie było ograniczone do danych niezbędnych. Wspomniany przepis RODO definiujący zasadę minimalizacji jest natomiast niejednoznaczny. Warto zatem przeanalizować stanowiska PUODO i WSA w omawianej sprawie.

Organ stwierdził, że przetwarzanie danych biometrycznych nie jest niezbędne do osiągnięcia celu, jakim jest identyfikacja uprawnienia dziecka do odebrania obiadu. Identyfikację można przeprowadzić za pomocą innych środków, mniej ingerujących

\footnotetext{
6 Dyrektywa 95/46 Parlamentu Europejskiego i Rady z dnia 24 października 1995 w sprawie ochrony osób fizycznych w zakresie przetwarzania danych osobowych oraz swobodnego przepływu tych danych (Dz. Urz. WE L 281, s. 31; dalej: dyrektywa 95/46).

7 Ustawa o ochronie danych osobowych z dnia 29 sierpnia 1997 r. (tekst jedn.: Dz. U. z 2016 r., poz. 922).
} 
w prywatność dziecka korzystającego z usług stołówki szkolnej. W szkole istniały alternatywne metody, takie jak karty elektroniczne lub podanie nazwiska i numeru umowy.

Wojewódzki Sąd Administracyjny w Warszawie podszedł do tej kwestii inaczej, przede wszystkim analizując bardzo szczegółowo stan faktyczny oraz cel przetwarzania danych.

Sąd zwraca w pierwszej kolejności uwagę na treść motywu 39 preambuły RODO, który stanowi m.in., że "(...) dane osobowe powinny być adekwatne, stosowne i ograniczone do tego, co niezbędne do celów, dla których są one przetwarzane. Wymaga to w szczególności zapewnienia ograniczenia okresu przechowywania danych do ścisłego minimum. Dane osobowe powinny być przetwarzane tylko w przypadkach, gdy celu przetwarzania nie można w rozsądny sposób osiągnąć innymi sposobami (...)". Sąd w swoim wywodzie na tle zasady minimalizacji i powyższego motywu, kładzie nacisk na odpowiednie zdefiniowanie celu przetwarzania i stwierdza, że dane „muszą być odpowiednie i stosowne do osiągnięcia celu ich zebrania, lecz zarazem nie mogą być nadmierne". To prawidłowo określony cel determinuje zakres niezbędnych danych ${ }^{8}$. Tym samym - wskazuje WSA - przetwarzanie danych w zakresie zbędnym dla osiągnięcia tego celu będzie oznaczało naruszenie przepisów RODO.

Sąd przyznaje w uzasadnieniu, że wymogi minimalizacji i adekwatności nie są ze sobą spójne, a ich spełnienie należy oceniać łącznie, co w konsekwencji oznacza, że „nie powinno się przyznawać prymatu minimalizacji kosztem adekwatności" ${ }^{9}$. Jednocześnie podkreśla, jak ważne są okoliczności konkretnej sprawy, a więc w tym przypadku fakt, że biometria nie była jedyną metodą weryfikacji płatności oraz to, że szkoła wprowadzała wcześniej inne sposoby weryfikacji odpłatności za posiłek (np. karta obiadowa) i dopiero stwierdzając, że nie przynosi to efektów, na wniosek rady rodziców i za pisemną zgodą rodziców, zdecydowała się na wprowadzenie czytnika biometrycznego. Słusznie sąd odrzuca sugestię PUODO, że dane biometryczne mogą być wykorzystywane tylko wyjątkowo, i to w takich celach, jak np. bezpieczeństwo osobowe, przemysłowe czy ochrona informacji itp. Takie ograniczenie znikąd bowiem nie wynika. Oczywiste jest, że sięganie po dane biometryczne jest daleko idącą ingerencją w sferę prywatności, niemniej nie oznacza to, że w przypadkach takich jak w gdańskiej szkole ich użycie będzie niedopuszczalne niezależnie od okoliczności. Słusznie zatem sąd, biorąc pod uwagę okoliczności sprawy, dopuścił możliwość weryfikacji biometrycznej uczniów.

Użyte w przepisie art. 5 ust. 1 lit. c RODO określenie „adekwatne” oznacza „odpowiednie, zgodne, proporcjonalne, nienadmierne" i może być traktowane jako synonim słowa „stosowne”. Pojęcia adekwatności i stosowności rozumieć można jako konieczność zachowania - jak stwierdza WSA - „odpowiednich proporcji zakresu danych do celów przetwarzania i przetwarzanie tylko takich danych, które są potrzebne dla

\footnotetext{
8 Tak: D. Lubasz [w:] Ochrona danych osobowych. Meritum, red. idem, Warszawa 2020, s. 114.

9 W literaturze zwraca się uwagę na problem interpretacji zasady minimalizmu; m.in. P. Fajgielski twierdzi, że ograniczanie danych do niezbędnego minimum byłoby interpretacją zbyt daleko idącą (idem, Ogólne rozporządzenie o ochronie danych. Ustawa o ochronie danych osobowych. Komentarz, Warszawa 2018, s. 149).
} 
realizacji określonych celów". Sąd wprost przyznaje, że ograniczenie danych do niezbędnego minimum - tak jak chce tego organ - byłoby interpretacją zbyt daleko idącą.

Najważniejszym elementem konkluzji sądu jest stwierdzenie, że wymóg niezbędności należy odczytywać łącznie z wymogiem adekwatności i stosowności, co powinno pozwolić na uwzględnienie okoliczności i dopuszczenie przetwarzania danych, które w istotny sposób mogą pomóc osiągnąć cele przetwarzania.

Co do zasady podzielam wyrażony przez WSA w glosowanym wyroku pogląd na temat rozumienia zasady minimalizacji, jednakże z pewnymi zastrzeżeniami. Przede wszystkim, przeformułowałbym nieco to rozumienie w następującym kierunku: w zasadzie minimalizacji nie powinno dostrzegać się konfliktu pomiędzy tym, co z jednej strony - „odpowiednie” i „stosowne”, a z drugiej - „niezbędne”. Wydaje się, że w pierwszej kolejności należy brać pod uwagę adekwatność (odpowiedniość) danych do określonego celu, z zastrzeżeniem że cel powinien być prawidłowo sformułowany. Zauważyć należy bowiem, że w omawianej sprawie nie wyartykułowano wyraźnie, iż chodzi nie tylko o samą weryfikację płatności, ale również o sprawność tego procesu, biorąc pod uwagę takie okoliczności jak liczbę uczniów korzystających z obiadów, czas w jakim są wydawane obiady, nieskuteczność dotychczasowych metod itp. Tak określony cel pozwala dopiero na określenie danych niezbędnych do jego realizacji. Innymi słowy, po określeniu danych osobowych odpowiednich (adekwatnych i stosownych w rozumieniu art. 5 ust. 1 lit. c RODO) do celu, administrator powinien potraktować ten zakres jako niezbędny do jego realizacji. Taka interpretacja pozwoliłaby na uniknięcie traktowania sformułowań użytych w ww. przepisie jako przeciwstawnych.

\section{Literatura}

Fajgielski P., Ogólne rozporządzenie o ochronie danych. Ustawa o ochronie danych osobowych. Komentarz, Warszawa 2018.

Ochrona danych osobowych. Meritum, red. D. Lubasz, Warszawa 2020.

Ogólne rozporzadzenie o ochronie danych osobowych. Ustawa o ochronie danych osobowych. Wybrane przepisy sektorowe. Komentarz, red. P. Litwiński, Warszawa 2021.

\section{Streszczenie}

\section{Arwid Mednis}

\section{Wykorzystanie danych biometrycznych w szkole}

Wojewódzki Sąd Administracyjny uchylił decyzję organu ochrony danych nakazującą szkole usunięcie biometrycznych danych osobowych w postaci linii papilarnych palców dzieci korzystających z usług stołówki szkolnej, zaprzestanie zbierania powyższych danych osobowych oraz nakładającą na szkołę karę pieniężną w wysokości 20 tys. zł. Kluczowa w sprawie okazała się kwestia zastosowania zasady minimalizacji (art. 5 ust. 1 lit. c RODO). Sąd stwierdził, że wymogi minimalizacji i adekwatności, o których mowa w tym przepisie nie są ze sobą spójne, a ich speł- 
nienie należy oceniać łącznie, co w konsekwencji oznacza, że nie powinno się przyznawać prymatu minimalizacji kosztem adekwatności. Sąd przyznał, że użycie przez szkołę danych biometrycznych nie było jedynym dostępnym sposobem weryfikacji, czy uczeń ma opłacone obiady, niemniej zwrócił uwagę, że okoliczności sprawy wskazywały na to, że użycie innych sposobów okazało się nieskuteczne. Co do zasady należy zgodzić się ze stanowiskiem sądu z zastrzeżeniem, że w sprawie nie chodziło jedynie o skuteczną weryfikację dokonanych płatności, ale również o sprawność procesu weryfikacji (duża liczba uczniów, krótki czas na sprawdzenie). Dopiero tak rozumiany cel pomógłby określić jakie dane osobowe są odpowiednie do jego realizacji.

Słowa kluczowe: zgoda; biometria; przesłanki legalizacyjne; dobrowolność; wycofanie zgody; zgoda dziecka; forma zgody; RODO.

\section{Summary}

\section{Arwid Mednis}

\section{Use of Biometric Data at School}

The Voivodship Administrative Court revoked the decision of the data protection authority ordering the school to remove biometric personal data in the form of fingerprints of the fingers of children using the school canteen services and to stop collecting the above personal data, as well as imposing on the school an administrative fine of PLN 20,000. The key issue in the case was the application of the minimization principle (Article 5 (1) (c) of the GDPR). The court stated that the requirements of minimization and adequacy referred to in this provision are not consistent with each other and their fulfillment should be assessed jointly, which consequently means that the primacy of minimization should not be given at the expense of adequacy. The court acknowledged that the school's use of biometric data was not the only available means of verifying that the student had paid for lunches, but noted that the circumstances of the case indicated that the use of other methods had proved ineffective. As a rule, one should agree with the court's position, however with the reservation that the case was not only about effective verification of payments made, but also about the efficiency of the verification process (large number of students, short time to check). Only the purpose understood in this way would help to determine what personal data are appropriate.

Keywords: consent; biometrics; lawfulness of processing; voluntariness; withdrawal of consent; consent of the child; form of consent; GDPR. 